\title{
Obecné vzdělávací kvality a pojem kompetence
}

\author{
Jana Dlouhá \\ Envigogika 2009/IV/1 - Recenzované články/ Reviewed Papers \\ Publikováno/Published 31. 05. 2009
}

DOI: http://dx.doi.org/10.14712/18023061.35

\begin{abstract}
Abstrakt:
V období transformace vzdělávacích cílů, metod a způsobů hodnocení výstupů

První z článků, který vznikl jako polemika s texty Jana Činčery (2008b, 2009) zaměřenými na hodnocení proenvironmetálního chování coby výstupu vzdělávacího procesu. Ukazuje význam a prioritu položených otázek před (metodicky podloženými) odpověd'mi - otevírá problém přínosu environmentálního vzdělání $v$ jeho širších souvislostech, především ve vztahu ke všeobecným vzdělávacím cílům. Z tohoto úhlu pohledu se jako žádoucí vzdělávací "kvalita" jeví nejspíše "kompetence" tak, jak ji definují současné odborné i strategické dokumenty. Koncept je podroben úvodní analýze s ohledem na povahu kompetencí a jejich potenciál pro inovace či změnu vzdělávacích paradigmat. Stručně jsou shrnuty jeho "vývojové potiže", především nedostatek nástrojů pro hodnocení.
\end{abstract}

\section{Klíčová slova:}

Teorie vzdělání, kultura dynamického studia, kompetence ve vzdělání, posouzení

\author{
Abstract: \\ procedures \\ In the period of transformation of learning goals, methods and evaluation
}

Text is a polemic with the concept of pro-environmental behavior considered to be the main environmental educational outcome by Jan Činčera in Envigogika articles published in 2008 and 2009. It shows the importance of questioning the problem before methodological elaboration into a set of educational goals and more general conclusions. Thus, the question of environmental education as a specific type of "adjectival" education is opened in the broad educational context, especially with regard to the future vision and ideas in UNESCO's Learning: the Treasure Within Report and other documents. From this very general viewpoint, the quality required in education should be expressed as "competences" rather than behavior; in this sense the "competences" are currently being defined in research articles and strategic educational papers. The concept of competences is further analyzed with regard to its character and potential for innovations or changes towards a more dynamic learning culture. Briefly its "evolutionary deficiencies", especially the lack of assessment methodologies, are summarized. 


\section{Key words:}

Learning theories, dynamic learning culture, competences in education, assessment 


\section{Úvod}

V situaci, kdy vzdělávací programy připouští pluralitu koncepcí a metod (vyjádřenou mj. přívlastky jako „environmentální"), nabývá na významu explicitní vyjádření přínosů takto vymezených vzdělávacích přístupů nebo jednotlivých programů, a dále hodnocení jejich výsledků. Taková evaluace má pak umožnit srovnání mezi těmito různými přístupy založené na určitých kritériích, která fungují podobně $v$ rozdílných vzdělávacích prostředích, tedy musí vycházet ze společných, obecně definovaných cílů vzdělání. Jelikož tyto obecně použitelné nástroje hodnocení mají současně postihnout specifické rysy určitých typů pedagogiky, je třeba hledat zvláštní kvality těchto alternativních metod a pokusit se vyjádřit je jazykem pedagogických teorií.

\section{Definice pojmů}

Text si nečiní ambice zavádět nové pojmy pro vzdělávací praxi, usiluje však o hlubší porozumění vzdělávacích cílů touto praxí stanovených, a to zobecněním zavedeného pojmosloví a jeho reflexí z této teoretické úrovně. $V$ této rovině si vypomáhá termínem vzdělávací kvalita, který se pokouší vymezit či definovat na základě obecných přínosů vzdělávacího procesu a jeho celkem dobře popsaných a konkrétních výstupư, např́klad znalostí, dovedností, kompetencí atd. Pojem kvalita tak znamená (více či méně určitou) schopnost, učením rozvinutou individuální dispozici, již si student ze vzdělání odnese; slovo samo pomíjí jednotlivé, historicky proměnlivě upřednostňované odlišnosti jednotlivých složek. Zobecnění $v$ pojmu kvality obsažené tak umožňuje převést na společného jmenovatele dílčí a rưznorodé schopnosti dosažené ve vzdělávacím procesu (znalosti, dovednosti, kompetence atd.), a ty potom chápat jako určité prvky nebo podmnožiny $v$ rámci kvalit obecných. Taková generalizace pak poskytuje základ pro hledání podílu těchto prvků v obecných vzdělávacích výstupech, srovnávat je mezi sebou z hlediska př́nosů pro individuální rozvoj, pozorovat vývojové trendy, kladoucí důraz vždy na některé z nich, nebo přemýšlet o všeobecných cílech vzdělání, z nichž jsou odvozovány konkrétní cíle a žádoucí výstupy atd. Hovoříme-li tedy v tomto textu o kvalitě, nejde nám o popis "jakosti" celého vzdělávacího prostředí nebo jeho části, ale o jev více či méně pozorovatelný na jisté osobě nebo skupině osob a související s určitými hodnotami, jichž je možno dosáhnout vzděláním; takových, které jsou pro tento individuální rozvoj považovány za vhodné, žádoucí. ${ }^{1}$ Každou kvalitu je možno popsat kvalitativně (právě jako onu individuální dispozici s určitými charakteristikami nebo vlastnostmi) a dále kvantitativně (jakožto míru naplnění této dispozice - například pomocí indikátorů nebo veličin) ${ }^{2}$

Environmentální vzdělání budeme považovat v kontextu českých debat na toto téma (a v návaznosti např́klad na Činčeru, 2008a) za pojem, který v podstatě pokrývá obsah mezinárodně zavedeného pojmu vzdělání pro udržitelný rozvoj („education for sustainable

\footnotetext{
1 Zde zcela úmyslně polemizujeme s pojmem kvality vzdělávání, jak jej vymezuje například Průcha (2000): "Kvalita (vzdělávacích procesù, vzdělávacích institucí, vzdělávacího systému) je žádoucí úroveň fungování anebo produkce těchto procesů nebo institucí, která může být objektivně měřena a hodnocena". Naší snahou je odlišit kvalitativní přístup od kvantitativního, který teprve dává základ pro měření a hodnocení ( $z$ tohoto hlediska obsahuje výše zmíněná definice protimluv, projevující se ve slovním spojení "kvalita je úroveň..."). Taková definice navíc již a priori počítá s existencí nějakého externího standardu, vưči němuž je míra dané kvality posuzována: jde o „...žádoucí úroveň" - a tedy tento postup nepodporuje rozvíjení vnitřních, inherentních kvalit vycházejících například z oblasti afektivní.

${ }^{2}$ Tento popis není totožný s kvalitativním či kvantitativním hodnocením vzdělání jako takového, které se může zaměřovat na jiné aspekty vzdělávacího procesu, než jsou individuální dispozice $v$ něm rozvíjené. Je samozřejmé, že teprve určitý souhrn různých přístupů k hodnocení vzdělání - tedy hodnocení kvalitativní spolu s kvantitativním - dává ucelený a plastický obraz o různých vlastnostech a funkcích vzdělávacích systémů a nástrojů používaných v jejich rámci.
} 
development, ESD") a v našich podmínkách jej nahrazuje. ${ }^{3}$ Pokud tento termín budeme zkracovat, můžeme využít anglické zkratky ESD (svou koncepcí přibližně odpovídá českému výrazu, o který nám jde). Je totiž libozvučnější; zkratka EV je navíc nejednoznačná, mưže znamenat vzdělávání ekologické.

\section{O co nám jde, co chceme analyzovat?}

Chceme především zjistit, co je ve velmi obecné rovině považováno za dílči vzdělávací kvality, tedy schopnosti, na jejichž pěstování se proces vzdělání zaměřuje, a jak se tato představa vyvíjí v současnosti. Kvality jsou rozvíjeny na individuální úrovni, přesto však spolu vytvářejí jednotné vzdělávací prostředí, které je z určitého hlediska v souladu se stavem a potřebami společnosti. Nás tedy bude zajímat, jak se popisuje souhrn všech kvalit představující dobré, kvalitní naplnění vzdělávacích cílů, žádoucí vzdělávací systém, a jak se $v$ jeho rámci berou $v$ úvahu různé cíle a úhly pohledu vyjádřené prvky tohoto systému, kvalitami dílčími (podrobně o vztahu mezi individuálními dispozicemi, schopnostmi a procesem učení viz De Raad \& Schouwenburg, 1996).

Jak vyplývá $z$ řečeného $v$ předchozí kapitole, jednotlivé kvality by měly být definovány dostatečně obecně, ale současně tak, aby je bylo možné specifikovat pro různé kontexty (úrovně vzdělání, cílové skupiny atd.). Měly by také být definovány $v$ rámci vzdělávacího diskursu - tedy tak, aby je bylo možné dosáhnout pedagogickými prostředky (metodami), aby byly $v$ souladu $\mathrm{s}$ obecnými vzdělávacími cíli, a nebyly odvozeny (jen) z nároků, které na vzdělání kladou potřeby společnosti, především jejího ekonomického metabolismu. Vymezení těchto kvalit a poznání jejich vzájemných vztahů ve vzdělávacím systému by mělo umožnit hodnocení procesu vzdělání, zajistit porovnatelnost jeho výsledků, a na tomto základě otevřít cestu k jeho zlepšování.

Pojem kvalita je do značné míry normativní, zahrnuje určité hodnotící stanovisko; zde, $v$ tomto textu pokládáme hodnoty $v$ nich obsažené za odvozené ze všeobecných vzdělávacích hodnot, nikoli těch, které plní ve vzdělání roli instrumentální, nadbíhají jen potřebám praxe, jež není praxí životní.

\section{Z čeho vyjdeme?}

Nejdřive vymezíme myšlenkové hřiště, na kterém se pohybujeme. Dokumenty, které určují pravidla hry v tomto prostoru, se budeme zabývat až později, nebot' představují odvozenou rovinu uvažování. Předpokládáme tedy, že jsme schopni najít principy, které vyplývají z povahy věci: tedy vzdělání jako takového a specifik prístupů environmentálních.

První premisa: Vzdělání má být kvalitní - tedy souhrn kvalit $v$ jeho rámci dosahovaných má mít pozitivní hodnotu. Nekvalitní vzdělání nemá smysl, aby bylo: jestliže latinské educare znamená vedení, vyvádění, pak důsledkem zavádění by bylo zbloudění, sebe-ztracení v labyrintu světa. Jednotlivé vzdělávací kvality mají - dle přístupu zde obhajovaného - přispívat svým podílem ke kvalitě celkové.

Premisa druhá: Kvality ve vzdělání, které jsou, jak již bylo řečeno, pozitivními individuálními dispozicemi, Ize posuzovat ze dvou hledisek: subjektivně, jakožto kroky na životní pouti, jež ji orientují $v$ souladu $s$ vlastním rozvojem a přinejmenším nikoli do

\footnotetext{
3 Naše pojmosloví navazuje na závěry konference $v$ Tbilisi konané již $v$ r. 1977, kde je environmentální vzdělání definováno následujícím zpưsobem: "Cílem ... je 1. posílit naše vědomí a porozumění ekonomické, sociální a ekologické provázanosti v městských i venkovských oblastech; 2. poskytnout každému príležitost dosáhnout znalostí, hodnot, názorủ, odpovědnosti a dovedností $k$ ochraně a zlepšování životního prostředí; 3. tvořit nové vzorce chování jednotlivců, skupin i společnosti jako celku vstřícné k životnímu prostředí. " Tuto definici rozvíjí ve smyslu patrném z tohoto textu.
} 
slepých uliček; anebo jako objektivní „výstupy" vzdělávacího procesu, jimiž člověk může vykázat určitou zdatnost před jinými, tedy v sociálním kontextu. ${ }^{4}$

Subjektivně oceňované, přijímané kvality ukazují svou povahu a prípadnou užitečnost až $v$ průběhu života, $v$ celostní dimenzi. Vznikají ve výchovném procesu, který vychází z nejhlubšího založení člověka a souvisí s jeho základní orientací, napětím mezi dobrem a zlem. Taková výchova souvisí s pojetím školy jako scholé, prázdného (časového) prostoru pro rozvinutí individuálních předpokladů a lidské individuality jako takové. ${ }^{5}$ Jejím základem jsou nejobecnější lidské vlastnosti: všichni potřebujeme lásku, péči, uznání, respekt, smysl a cíl, o který usilujeme - nemáme-li je, náš život i úsilí jsou nutně neplnohodnotné. Tyto podmínky jsou oporami nejen vnitřních struktur vědomí a psychologického ustrojení člověka, ale také výchovy, která na ně má působit a je proměňovat. Nejsou-li okolnosti duchovního rozvoje příznivé, nedaří se ani cíle více odvozené, např́klad osvojení určitých návyků či znalostí. Takto jsou subjektivní kvality vázány na všeobecné vzdělávací cíle, nikoli konkrétní okolnosti; dimenze jejich působení je celoživotní, mohou se projevit až v dlouhodobém časovém horizontu.

Objektivní výstupy daleko více souvisí s požadavky kladenými na vzdělání zvenčí, osvědčují se nikoli pro životní orientaci člověka, ale pro jeho základní orientovanost v systémech společenského provozu a soužití. Vztahují se vždy ke konkrétní roli anebo úkolu, ve kterém je angažován, pro nějž má mít předpoklady. Tak vycházejí kvality druhého druhu z určitého praktického kontextu, jsou více specifické - nemají obecné rysy a společného jmenovatele. Kontext, $v$ němž je nalézáme, vymezuje určitým způsobem jejich povahu a omezuje použitelnost pojmu, kterým je popisujeme, na určité situace; přesto jsou lepším základem pro srovnání, nebot' jejich objektivní hodnocení je možné i z krátkodobého hlediska (kdežto kvality subjektivní nemusejí být nutně v krátkém časovém odstupu patrné).

Popis kvality (jakosti) vzdělávacího systému pomocí kvalit jen jednoho druhu je nutně neúplné. Obojí způsob hodnocení je zatížen chybou pozorovatele, v prvním prípadě

\footnotetext{
${ }^{4}$ Ve filosofickém diskursu se tato dvě hlediska ukazují podobně, avšak s opačnou orientací vzhledem k vlastní osobě: ono "subjektivní má transcendetnální rozměr a tedy naopak platnost obecnou. Vychází se z následující úvahy: „Přirozeně, že výchova vždycky je nějak situována a že situace proměňuje povahu výchovného činění. Něco ale $v$ tom výchovném činění je konstantou a něco je proměnnou. ... Konstantou by mělo být zmíněné respektuplné vyvádění $z$ egocentricity $k$ reálným a pravým hodnotám, tedy jakýsi druh transcendence. Transcendencí v této souvislosti míním pouze schopnost vystoupit a podívat se sám na sebe a na svou aktuální situovanost.

Výchova má dva žretele. Jednak je to uvádění do kvalitní, perfektní odbornosti v určitých vymezených parciálních zkušenostech, např. v řemesle nebo ve vědě, jednak vždy ještě cosi navíc. ..." ( Palouš, 1994a)

${ }^{5}$ Individuální růst je skutečným vývojem jen za určitých okolností: především pokud je založen na vztahu $\mathrm{k}$ tomu, co individuum přesahuje, co se netýká bezprostředně jeho života. $\mathrm{K}$ tomu, aby tento rozměr výchovného působení se mohl osvědčit, je zapotřebí vhodného prostředí, uvolnění z každodennosti a jejích požadavků: „Řecký výraz scholé znamená prázdeň a ascholia zaneprázdněnost (totiž v latině otium-negotium). V obou prípadech je výraz pro prázdeň pozitivní, avšak pro zaneprázdněnost je negativní. I Komenský školu koncipuje ne proto, aby byli lidé ,prakticky' zdatní. Ve Veječce moudrosti píše, že nenapsal svou didaktiku kvưli umění pekařskému nebo malířskému nebo gramatickému, ba ani logickému, nýbrž že mu jde o ,didaktiku života'.

Ještě celé 18 . století myslí $v$ souvislosti $s$ výchovou a vzděláním především na celkovou osvětu. Všechno to, čemu se dnes říá školní řemeslná, odborná, střední a vysoká príprava, to všechno se zdaleka nepovažovalo za ,školu'. Když otec učil svého syna orbě a mistr tovaryše řemeslu, to nebyla škola, školení, to prostě byl denní provoz se vším všudy. Terpve v 19. století s vnikáním vědy do průmyslu začíná vznikat škola jakožto příprava na výrobu a ovšem i na občanský život vůbec. ..." (Palouš, 1994a)
} 
jeho osobním hlediskem ${ }^{6}, \mathrm{v}$ př́padě druhém kritériem, které kvalitu (jakožto kvalitu) popisuje a dle toho prípadně kvantifikuje.

Premisa třetí: Přes veškerou nejednoznačnost je třeba o hledání kvalit ve vzdělání a o jejich hodnocení stále usilovat; takové hodnocení je ovšem také soustavným přehodnocováním $\mathrm{s}$ ohledem na to, že spolu s přirozeným rozvojem osobnosti (pokud jde o hodnocení subjektivní) nebo vztažné soustavy, vǔči které se hodnocení provádí, tedy např́klad společnosti, její kultury a požadavků na vzdělanost ( $v$ př́padě druhém, objektivním), se mohou měnit úhly pohledu a kritéria, jimiž vzdělání posuzujeme.

\section{Jsou kvality environmentálního vzdělání v něčem zvláštní?}

Tedy - přináší environmentální vzdělání (zcela) nové jevy, pěstuje takové individuální dispozice, jejichž povaha je specifická vzhledem k jiným „typům" vzdělání?

Odpověd' zní: ano, úsilí o re-orientaci vzdělání tímto směrem je mnohými autory pokládáno za významný paradigmatický posun?. Dokonce, i když nechceme př́liš radikálně

${ }^{6}$ Toto osobní hledisko hraje významnou úlohu i ve filosofickém diskursu, kde "subjektivní (ve zde prezentovaném pohledu) kategorie kvalit má transcendentální, obecně platný rozměr. Individuální život se má v této nadosobní rovině obracet k idejím, které jsou interpretovány jakožto "platné, závazné, účinné, ale nejsoucí"; cesta k nim je pak pro nás osobní výzvou (tedy nikoli nějakým předpisem platným pro všechny stejně - viz např. Hejdánek, 1994: 89).

7 Zavádění environmentálních programů do školního kurikula představuje $v$ praxi zásadní rozpor s dominující koncepcí a organizací vzdělání i způsobem předávání znalostí, a způsobuje konflikt $\mathrm{s}$ běžným přistupem $\mathrm{k}$ výuce a učení. Je spatřován zásadní rozpor mezi environmentálním vzděláním a tradičním zaměřením školství, které má spíše konzervovat současný sociální řád reprodukcí převládajících norem a hodnot (Stevenson, 1987). Nutnost odvratu od tradičních hodnotových schémat přispívajících k environmentální degradaci podle některých autorů znamená, že je třeba hodnotovou oblast revolučním způsobem transformovat (Tanner, 1974).

Přístupy ke vzdělání jsou $v$ oblasti environmentální $z$ principu alternativní, hovoří se o reflexi zásadních paradigmat a jejich proměně (Gough, 1987). Cílem je především hlubší porozumění fenoménům (jakási paralela $\mathrm{k}$ hlubinné ekologii), jehož výsledkem by mělo být holistické, na spoluúčasti založené vědění vycházející z dialogického vztahu ke světu (Reason, 1988). V praxi jsou mezi tradičním a environmentálním vzděláním spatřovány zásadní rozpory obsahové a metodické. Tradiční pojetí trvá na disciplinárním přístupu a zdůrazňuje abstraktní teoretické problémy. Obecně má být kladen důraz na zpracování rozmanitých informací, vytváření konceptů a zobecnění; učitelé jsou angažováni $k$ předávání existujících znalostí a studenti jsou $v$ pasivní roli př́jemce daného vědění. Již dávno se ovšem zjistilo, že pokud se chceme se orientovat více na praktické záležitosti např́klad ochrany prostředí, vyvolává to potřebu interdisciplinárního a pružného zkoumání skutečnosti, ve které jsou studenti aktivně angažováni. Zde se tedy zdůrazňuje "holismus" v teoretickém přístupu, způsobu vnímání a také praktických konceptech (např́klad organizačních rámcích). Z toho vyplývá především odlišnost $v$ předmětové organizaci učiva. Environmentální problematika bývá začleňována do přírodních věd a teoretická východiska jí často poskytuje ekologie. Témata však jdou "napříc učivem" směrem $\mathrm{k}$ vědám společenským, a na této cestě boří disciplinární hranice i některá vědou postulovaná tabu. Na holistickém základě se ale také široce uplatňují vztahy spolupráce a vzájemné podpory; tento odklon od vztahů konkurenčních, jež jsou jedním z hlavních ( $v$ současné době působících) sil $v$ celospolečenské dynamice, také představuje jeden z hlavních posunů či přínosů, které s sebou environmentálního vzdělání má nést.

Výše jmenovaní autoři dokládají, že klasické přístupy ve vzdělávacích systémech v mnoha ohledech zásadním způsobem brání rozvoji environmentálních programů (a naopak); např. Gough (1987) vidí nutnost přechodu od materialistického a atomistického názoru a epistemologického paradigmatu, které jsou ve formálním vzdělávání dominantní, k více "ekologickým" přístupům. Navrhuje, aby byly zkoumány vzdělávací struktury a paradigmata, které jsou v zásadě filosofií zakládající konkrétní podobu vzdělání, a to s výhledem na její možnou rekonstrukci. Říká, že náš současný vzdělávací systém spoléhá na takové porozumění skutečnosti, přírody a lidské přirozenosti, které již nemưže být považováno za určující.

Pozitivní myšlení formuje (z ekologického hlediska nežádoucím způsobem) také sebepojetí člověka, nebot' $v$ důsledku vědeckotechnické revoluce se stále více prosazují hodnoty instrumentální. Lidská bytost je spatřována jako subjekt zásadně vyčleněný $z$ prírody a mající nárok $s$ ní libovolně 
měnit základní východiska, představují kvality environmentální ve vzdělávacím prostředí jistou dobře patrnou „přidanou hodnotu”. Tento typ vzdělání má své specifické cíle, metody a výsledky, a určité zvláštní kvality jsou jejich výsledkem. Je potřeba je najít, pojmenovat a vymezit, a dále s nimi pracovat zpưsobem zcela adekvátním - např́klad hledat zvláštní způsoby jejich hodnocení. Pak by environmentální vzdělání mohlo být definováno na základě těchto „přidaných hodnot”, cílů souvisejících s jejich dosažením, a prostředků či metod doprovázejících úsilí takto orientované.

Podotázka: Je možné, že je environmentální vzdělání postaveno na zcela vlastních základech, které jsou v rozporu s obecnými vzdělávacími cíli?

Mezi obecné vzdělávací cíle 8 patří především snaha o přivedení člověka k sobě samému i ke kultuře a společenství lidí, se kterými chce sdílet životní prostor. Otázku po základním paradigmatickém rozporu tedy pomineme - pokud by existoval, vedlo by environmentální vzdělání k sociálnímu vyloučení, což cílem vzdělávacího procesu rozhodně není. Jiným problémem ovšem je, že také $v$ jiných oblastech pravděpodobně Ize nalézt vzdělávací programy, které se považují za legitimní, které však nesledují všeobecné vzdělávací cíle $v$ dostatečné míře, nevedou např́klad plně $k$ rozvoji osobnosti člověka, jsou jednostranné, sledují cíle kariérní anebo manažersky definované, a k sociálnímu vyloučení vedou také - i když to je $v$ tomto př́padě nazýváno exkluzivita, výjimečnost, úspěšnost atd. Environmentální vzdělání však nemá poukazovat na nevhodnost těchto výlučných a vylučujících přístupư tím, že zaujme pozice sice excentricky opačné, také ovšem exkomunikující.

Je třeba vzdělávací kvality nakonec hodnotit - a pokud ano, tedy jak?

Pokud by kvality tak, jak jsme je vymezili, byly pomůckou jen teoretickou, nemohly by ovlivňovat či uvádět do pohybu procesy, jimiž se vzdělávací prostředí a nástroje neustále obnovují a transformují pro potřeby nových situací. O těchto kvalitách by tedy např́klad jistá skupina vzdělavatelů věděla, mohla by na jejich základě pěstovat určitou vzdělávací kulturu, ale nebyla by schopna výsledky svého úsilí nijak obhájit, legitimovat na základě evidence. Taková pedagogika by se mohla stát základem nekritického, nebo až dogmatického přístupu či pojetí.

Jestliže je environmentální vzdělání v zásadě kompatibilní s jinými typy vzdělávání, a představuje jejich obohacení o další cíle nebo rozměr, má být také hodnocení kvalit, které přináší, v souladu s jinými, obecně použitelnými typy hodnocení - na ně navazovat. Vztahy $\mathrm{k}$ těmto jiným kritériím posuzování mají být specifikovány. Hodnocení by tak mělo ukázat kvality environmentálního vzdělání jako „přidané", doplňující; mělo by umožnit všestranné srovnání skupin studentů, kteří jimi disponují, s těmi, u nichž rozvinuty nebyly.

manipulovat. Vědění je ceněno na základě toho, jak se objektivně a racionálně potvrzuje nejen ve skutečnosti samé, ale také jak se ukazuje ve výstupech vzdělávacího procesu. Studenti jsou pak jen pasivními př́jemci již existujícího a ve svém základě neměnného poznání a jejich výkony jsou hodnoceny na základě kvantitativních ukazatelů (Stevenson, 1987). To vede $\mathrm{k}$ determinismu a nevytváří prostor pro rozvoj kritického myšlení, nezbytného při reflexi převládajících postojů a myšlenkových schémat.

Naopak environmentální vzdělání čerpá z nově vznikajících myšlenkových proudů, snaží se překonat vliv pozitivní vědy a vliv empirických teorií vnímání vytvořených filosofy 18 . století (Locke, Berkley, Hume). Klade důraz na holistické pojetí skutečnosti (oproti fragmentovaným poznatkům); výuka se dle ekologických teorií vnímání zaměřuje na podporu vztahů k prostředí a na učení se „prostřednictvím smyslư". Někdy je vyžadována zásadní reorientace př́stupu ke skutečnosti, sjednocení vědění na základě znovunalezených vnitřních hodnot, a tedy je zdưrazňován význam ekofilosofie. Více o problematice základních východisek a transformačních tendencí v environmentálním vzdělání viz např. (Dlouhá, 2006)

8 Tedy takové cíle, jež se ukazují v celostním pohledu na vzdělání, jsou součástí jeho holistických přístupů; pro použití v praxi jsou vyjádřeny např́klad ve zprávě Učení je skryté bohatství (Delors, 1997) atd. 
Posuzování př́nosů environmentálního vzdělání by tak mohlo být postaveno na objektivní základ, který Ize dále rozvíjet, podporovat, nebo též o něm diskutovat.

Pro naše další úvahy jsme došli k předběžnému závěru, že kvality environmentálního vzdělání mají být nalezeny a hodnoceny zvlášt', ale v návaznosti na všeobecné cíle a jejich kvalitativní vyjádření. Hodnocení vzhledem k jiným než těmto všeobecným vzdělávacím cílưm a miře jejich naplnění je také možné, avšak nevypovídá o kvalitách vzdělávacích, nepatří do pedagogického diskursu (viz následující př́klad).

Př́klad: Proenvironmentální chování by nemělo být považováno za kvalitu ve výše uvedeném smyslu. Nejedná se o individuální dispozici; jeho rozvíjení nevychází ze všeobecných cílů vzdělání; není dosažitelné čistě pedagogickými prostředky. Nepopisuje určitou vlastnost vzdělávané osoby, jež $v$ ní byla rozvinuta; schopnost, o niž byla obohacena, a tedy je třeba pokládat proenvironmentální chování za projev vnější, pouhý zprostředkovaný doklad jistých kvalit. Je tak spiše indikátorem, podle kterého Ize skutečné kvality posuzovat, např́íklad jako test znalostí indikuje dosažení kvalit kognitivních. Jako indikátor má značný význam pro sledování rozvoje dané oblasti, není ovšem cílem tohoto procesu. Zaměřit se na pěstování přiznivého environmentálního chování v rámci vzdělání a jeho metodických aj. nástrojů by tak bylo podobné, jako redukovat proces poznání na prípravu k úspěšnému zvládnutí znalostních testů.

Proenvironmentální chování, které samo o sobě není výstupem vzdělávacího procesu, $v$ jistém ohledu neplní ani svou funkci obecného hodnotícího kritéria. $K$ utváření proenvironmentálního chování daleko více přispívají vnější faktory, je tedy otázkou, co tento fenomén reprezentuje. Jeho podoba či míra je dále závislá na kombinaci různorodých předpokladů, jistých kvalit, na něž může být na různých stupních vzdělávacího systému kladen zcela odlišný důraz (např. na předškolní či ještě spíše vysokoškolské úrovni mohou být některé jeho konstitutivní složky - např́klad dovednostní, afektivní atd. - málo rozvíjeny). Pokud by tedy proenvironmentální chování bylo cílem učení, byla by poměrně problematická návaznost jednotlivých jeho stadií; jestliže má sloužit pro hodnocení výsledků vzdělávacích procesů, pak zase jen $v$ omezené miře poskytuje spolehlivý obraz o účinnosti vzdělávacích metod a umožňuje srovnání ve všech jeho rovinách a úrovních.

Závěr: Vzdělávací kvality stanovené jako cíle i kategorie pro posuzování výsledků vzdělávacího procesu by měly mít vztah ke vzdělávané osobě na jedné straně (stavět na péči o individuální dispozice, postupně se stávat inherentními schopnostmi či vlastnostmi), a ke všeobecným vzdělávacím cílům na straně druhé. Mají být $v$ těsné souvislosti $s$ všestranným rozvojem osobnosti člověka a $s$ jeho vztahem $k$ druhým lidem, $s$ jeho zařazením do společenství. V základu tohoto př́stupu je filosofie, která blaho jedince (jeho vnitřní růst a zrání) ztotožňuje s prospěchem společnosti, ve které svůj potenciál nakonec uplatňuje.

\section{Všeobecné vzdělávací cíle}

Všeobecné cíle vycházejí tradičního holistického pohledu na oblast vzdělání (viz např. Dlouhá, 2007), jsou základem specificky pedagogického př́stupu, podstatným znakem či principem, který tento pedagogický diskurs vymezuje (zakládá jeho svébytnost, nezávislost na jiných oblastech a formách poznání, např́iklad vědě). Mají platnost víceméně obecnou - na rozdíl od samotných vzdělávacích systémů, které jsou proměnlivé, v průběhu století se měnily $v$ závislosti na historickém kontextu, společenské situaci a také $\checkmark$ souvislosti $s$ filosofickými paradigmaty přijímanými $v$ dané době. Také $v$ praxi měly vzdělávací systémy vždy jeden společný rys - určitým způsobem předjímaly budoucnost. To znamená, že $\mathrm{ji}$ bud' předvídaly, nebo konstruovaly, utvářely ji - a utvářely se $\checkmark$ závislosti na ní. $V$ současné době se ale často hovoří o tom, že svět se mění př́liš rychle a vzdělání ztratilo schopnost reflexe vnitřní podstaty tohoto vývoje; s provinilým pocitem se ho snaží dostihnout pouze povrchními - kvantitativními - změnami. Soudí se, že 
vzdělávací systémy často fungují podle pravidel minulosti a vychovávají pro svět, který neexistuje. ${ }^{9}$ To ovšem může svědčit také o zapomínání na konstitutivní východiska vzdělání - obecné vzdělávací cíle.

Sféru teoretickou i praktickou spojuje poznání, že vzdělání nemá jen efektivně (metodicky) předávat určitý obsah, ale především chránit obecné výchovné (vzdělávací) hodnoty ${ }^{10}$, napríklad usilovat o rozvoj a využití individuálních schopností jednotlivce. Za měnících se podmínek představuje péče o tyto základní hodnoty stálou výzvu, na kterou je třeba vždy znovu reagovat. I z tohoto dưvodu byly v roce 1993 na pừdě UNESCO, v mezinárodní komisi "Vzdělávání pro 21. století”, formulovány čtyři základní pilíře vzdělávání, které jsou základem pro rozvoj tzv. učící se společnosti v globálním světě vycházejí ovšem z důrazu na rozvoj jedince. Tento tzv. Delorsův koncept čtyř pilírů vymezuje roli vzdělávání takto (Delors, 1997: 125):

- učit se poznávat, to znamená osvojovat si nástroje pochopení světa a rozvinout dovednosti potřebné k učení se;

- učit se jednat, to znamená naučit se tvořivě zasahovat do svého životního (tzn. př́rodního i společenského) prostředí;

- učit se být, to znamená porozumět vlastní osobnosti a jejímu utváření v souladu s obecně přijímanými morálními hodnotami;

- $\quad$ učit se žít společně, to znamená umět spolupracovat s ostatními, a moci se tak podílet na životě společnosti, nalézt v ní své místo.

Programově je tak deklarováno, že výsledkem vzdělání nemá být jen osvojení si například určitých znalostí, dovedností a postojů, ale též vytvoření jistých kapacit a schopností (kritické myšlení, autonomní učení, tvořivost atd.), které jsou pěstovány mj. prostřednictvím metod, toho, jak je výukový obsah předáván. Rozvíjení individuálních dispozic a svobody jednotlivce nemusí být z hlediska potřeb společnosti na prvním místě, vzdělávací systémy je však třeba chránit před riziky tohoto instrumentálního pojetí. Delorsův koncept má právě tento smysl: chce být všeobecným rámcem, ze kterého pak vychází rozpracování velmi specifických, konkrétních vzdělávacích cílư, aniž by tyto cíle reagovaly pouze na společenskou praxi.

Zmíněné čtyři pilíře jsou mimo jiné také podkladem kurikulární reformy, která právě v České republice probíhá; jsou zahrnuty i v Národním programu rozvoje vzdělávání (Bílá kniha, 2001). Hrají významnou roli také pro vzdělání environmentální (o této oblasti viz související článek v tomto čísle Envigogiky: „Kompetence v environmentálním vzdělání”).

\footnotetext{
9 Viz (Sterling In: Huckle \& Sterling, 1996: 24): „...Vzděláváme pro svět, který již neexistuje, to je dáno setrvačností celého systému. Svět suverénních národních států a mocenské stability, expandující ekonomiky, plné zaměstnanosti a celoživotního zaměstnání, globálního rozvoje, neomezenosti přírody, vědecké a morální určitosti v posledních desetiletích mizí. Tradiční představy a očekávání, že ústřední vlády mohou poskytnout úplný systém služeb, že Ize dosáhnout osobní ekonomické jistoty, že ekologické systémy mohou být stálým zdrojem i úložištěm, aniž by byly narušeny, se rozpadly. Kontrolovatelný a předvídatelný bezpečný svět je nahrazován světem, který je charakterizován komplexitou, vzájemnou propojeností, nejistotou a nedostatkem bezpečnosti - to Ize pozorovat na všech úrovních od lokální po globální a $v$ takových oblastech jako je ekonomika, osobní hodnoty a vědecké poznání. Současné postmoderní období charakterizuje nepředvídatelnost a chaos $v$ př́rodních i společenských systémech - jevy spoluvytvářené našimi minulými předpoklady a jistotami. Díky své systémové povaze problémy nemohou být řešeny technickými zásahy; přesto ale staré paradigma má stále silný vliv na myšlení, politiku a praxi v mnoha oblastech života.

Rostoucí vytváření nerovnováhy $v$ sociálním i př́rodním prostředí je znakem současné krize; ta může být interpretována jako výsledek pochybného vzdělávacího systému. Budoucnost bude vyžadovat takové lidské vlastnosti jako je pružnost, odolnost, tvořivost, participativní dovednosti, materiální omezení, vědomí odpovědnosti a transpersonální etika."

10 Podrobněji viz (Elliott, 1994: 38.)
} 


\section{Kategorizace vzdělávacích cílư}

Konkrétní vzdělávací cíle vycházející ze všeobecného rámce se člení podle běžně užívané tzv. Bloomovy taxonomie (Bloom, 1956) do tří oblastí (domén): a to na oblast kognitivní, afektivní a psychomotorickou. Na tomto teoretickém základě (paralelně k jednotlivým cílům či doménám) pak vzniklo tradiční členění vzdělávacích výstupů ( $k$ valit) na znalosti, dovednosti a postoje. Je možné tyto tradiční oblasti srovnat $s$ nověji vymezenými okruhy učení podle Delorse (tabulka 1)

Tabulka 1. Srovnání kategorií vzdělávacích cílů podle Blooma (1956) a Delorse (1997)

\begin{tabular}{|c|c|}
\hline $\begin{array}{l}\text { Bloomova taxonomie vzdělávacích cílů; } \\
\text { oblasti či domény (Bloom, 1956): }\end{array}$ & $\begin{array}{l}\text { Delorsův koncept; všeobecné cíle } \\
\text { vzdělání (Delors, 1997): }\end{array}$ \\
\hline kognitivní (znalosti) & učit se poznávat (learning to learn) \\
\hline \multirow{2}{*}{ afektivní (postoje) } & učit se být (learning to be) \\
\hline & $\begin{array}{l}\text { učit se žít společně (learning to live } \\
\text { together) }\end{array}$ \\
\hline psychomotorická (dovednosti) & $\begin{array}{l}\text { učit se jednat } \\
\text { (původní text: learning to do) }\end{array}$ \\
\hline
\end{tabular}

Vidíme určitý posun $v$ chápání jednotlivých kategorií vzdělávacích cílů i toho, jaké mohou/měly by mít důsledky pro vzdělávací praxi. V Delorsově konceptu nejsou pro kognitivní oblast již tak důležité znalosti jako takové, důraz se přesunul na procesjejich nabývání a udržitelnost či kontinuitu tohoto procesu v celoživotní dimenzi. Oblast psychomotorická se zde v překladu vytratila, jejím obsahem byl pưvodně skutečně rozvoj dovedností manuálních, v novějších verzích (např. Harrow, 1972; Simpson, 1972) ovšem doplněných o schopnost tyto činnosti plánovat, završit viditelným produktem, nebo provádět kreativně. Největší posun je možno spatřovat ve sféře afektivní, která se v tradičním pojetí soustřed'uje na přijetí určitých hodnot, jejich "zvnitřnění a následní „aplikaci" na situace každodenního života. Delors a jeho následovníci žádné takové externě založené, jedinci k přijetí předkládané hodnoty neprosazují; člověk má naopak být vybaven daleko flexibilnějším souborem vlastností, jejichž opodstatněnost se ověřuje $v$ praxi individuálního nebo společenského života. O důsledcích, které má takový vývoj pro tvorbu vzdělávacích cílů a hodnocení úspěšnosti při jejich naplňování, bude opět pojednáno podrobněji v dalším textu („Kompetence v environmentálním vzdělání).

\section{Hledání nových kvalit z hlediska praxe}

Kromě posunů ve vzdělávací teorii, které souvisí s velkými změnami v pohledu na svět (paradigmatické posuny) se $v$ konkrétních historických okolnostech proměňuje i vzdělávací praxe. Tyto transformace vzdělávacích systémů probíhají především vzhledem okolnostem praktického uplatnění absolventů (všech stupňů vzdělání), a tedy např́klad ve vztahu k potřebám trhu práce, v souvislostech $\mathrm{s}$ jeho aktuálním vývojem atd. - tak vznikají jisté aktuální trendy, které se zde pokusíme zachytit, nikoli však podrobně popsat. V tomto textu jde totiž především o sledování proměny všeobecných vzdělávacích konceptů a míru jejich vlivu na prakticky orientované cíle a strategie $v$ daném společenském kontextu. 
Za významnou charakteristiku vzdělávacích systémů se v současnosti považuje jejich proaktivní orientace (proaktivní = pưsobící dopředu), tedy schopnost předjímat budoucí vývoj. Na úrovni jedince se tak utváří "model člověka”, který má nejen určité znalosti, ale umí především jednat - to znamená je schopen využívat osvojených vědomostí a dovedností a adekvátně se rozhodovat, dokáže také přijímat podněty z okolí, nové situace předvídat, hledat variantní řešení a vyhodnocovat jejich dưsledky. Umí se adaptovat, vstupovat do nových vztahů, přijímat různé role v týmu. Disponuje souborem univerzálně použitelných dovedností - je k určitým činnostem kompetentní. Tato myšlenka je východiskem pro rozpracování konceptu kompetencí: klíčové kompetence postupně byly stanoveny jako strategický cíl vzdělávání na evropské úrovni, a mají se stát „prostředkem odemykání dveří do nových situací" (Walterová, 1998/9).

$\checkmark$ praktické rovině Ize tyto současné změny charakterizovat jako posun celkového zaměření výukové situace od čistě aplikačního (přeber a aplikuj řešení), které vede $\mathrm{k}$ pouhým replikacím a vytváření strnulých mentálních struktur. Z teoretického i praktického hlediska je výhodnější, aby výuka byla strukturována spíše činnostně; aktivity se $v$ takovém prípadě stávají modelem další práce. Akcent se přesouvá z poznatkového pole na metodu poznávání (Štech, 1999: 157-166).

Je ovšem třeba vidět, že pojem kompetence je, přes svou výraznou orientaci na praxi každodenního společenského provozu s jejími novými nároky, velmi dobře zakotven v základních a všeobecných cílech vzdělávání, jak byly formulovány ve čtyřech pilírích Delorsovy zprávy (1997). Tento koncept má povahu celostní, není určován pouze hledisky a kritérii dílčími, definovanými např́klad jako znalosti či dovednosti - každá jednotlivá kompetence zahrnuje $v$ sobě vždy celý komplex faktorů $\mathrm{s}$ ohledem na situaci, v níž se má projevit. Se čtyřmi pilíri rozvoje vzdělávacích systémů, které byly $v$ teoretické rovině určeny jako základní součásti kompetencí: tedy poznávání, jednání, bytí a společenský život, koresponduje poměrně dobře definice či vymezení čtyř hlavních okruhư či kategorií kompetencí, jakožto určitého praktického "výstupu" vzdělání: oborové kompetence, metodologické kompetence, osobní a sociální kompetence (Sleurs, 2004: 35).

K holistické povaze souhrnu transformačních procesů ve vzdělání, které už mají povahu proměny zásadních východisek a tedy paradigmatickou, přispívá i skutečnost, že stále většího významu nabývá tzv. celoživotní rozměr učení. Z této celostní perspektivy umožňuje proces získávání kompetencí člověku nejen uplatnit se na trhu práce a v pracovním životě, v reálných i virtuálních společenstvích a v demokracii, ale také nalézt vlastní identitu a stanovit si (nebo postupně přehodnotit) své životní cíle. ${ }^{11}$ Tak se vrací tradiční představa vzdělání jakožto apodemie, tj. cestování za poznáním. ${ }^{12}$

\section{Kompetence jako vzdělávací kvalita}

\section{Vývoj pojmu a konceptu kompetencí}

Dosud jsme zjistili, že změna úhlu pohledu na žádoucí výstupy ve vzdělání je spojena s pojmem kompetence. Podívejme se podrobněji, co tento nový termín znamená, a jak se postupně vyvíjel.

\footnotetext{
11 Viz Vyučování a učení. Cesta $k$ učící se společnosti. Office for Official Publications of European Communities. Český překlad Učitelské noviny - Gnosis, spol. s r. o., Praha 1997. Viz též Memorandum o celoživotním učení. § 4. Jednat ve prospěch celoživotního učení: šest klíčových myšlenek [Online] [Cit-2009-03-05] Dostupné z www: <http://www.nvf.cz/archiv/memorandum/ obsah.htm\#41>

12 Jde o Komenským akcentovaný pátý stupeň pedagogické soustavy, kdy člověk usiluje o sebezdokonalování i ve věku mužném a ve stáří (viz Kumpera, 1999) Výchova tak není jen a pouze nějakou přípravou na životní výkony, ale je především přiváděním člověka ke svobodě a zodpovědnosti. Stáří pojímá jako „....přivádění $k$ náležitému využití poslední lidské šance tváří v tvář celkovému smyslu..." (Palouš, 1994b)
} 
V 70. letech se uplatňoval koncept klíčových kvalifikací (zavedený v r. 1974 Mertensem v Německu) - soustředil se na znalosti, dovednosti a postoje, které jsou potřeba pro pružné reagování na potřeby profese a zaměstnání. Později se $v$ debatě o vzdělání a kurikulích začal klást důraz na flexibilitu - to souviselo se sociálními nejistotami a zvyšující se nepředvídatelností trhu práce. V 90. letech minulého století z tohoto důvodu přistup založený na kvalifikacích uvolnil prostor konceptu kompetencí, jež byly definovány jako kvality či schopnosti, které je možné vyučovat i naučit se, a díky nimž je možno se přizpůsobovat změnám anebo provádět požadované činnosti jako práci, učení, atd. Spolu s tím se změnil i zpưsob stanovení cílư vzdělání nebo posuzování jeho výsledkư, tedy kvality a efektivity - z hodnocení vstupů a vzdělávacích procesů na hodnocení výstupů, vzdělávacích kvalit, a to nikoli již ve formě znalostní (osvědčované při zkoušení či testech). Za významný výsledek byly považovány takové schopnosti, které se projevily až v určité situaci, a byly spojeny s uměním využít znalosti, nikoli je pouze získat, nabýt. Kompetence, jejich uplatnění a následné posuzování, "měření" míry jejich naplnění se tak stalo neoddělitelné od určité praktické situace.

\section{Terminologie}

Podle obecně přijaté definice představují klíčové kompetence přenosný a univerzálně použitelný soubor vědomostí, dovedností a postojů, které potřebuje každý jedinec pro své osobní naplnění a rozvoj, pro zapojení se do společnosti a úspěšnou zaměstnatelnost. ${ }^{13}$

V evropském kontextu není ovšem terminologie jednotná, pojem klíčové kompetence (key competencies) je zemím Evropské unie pouze doporučován pro označení souboru vědomostí, dovedností a postojů.

V českém pedagogickém pojmosloví nabývá termín kompetence nového významu oproti významu běžně užívanému a definovanému Slovníkem cizích slov - rozumí se jím soubor vědomostí a dovedností vytvářejících základní způsobilost pro výkon určité profese (Pedagogický slovník, 1996). Kompetence jsou různé, a různě se ovlivňující, schopnosti, z nichž některé jsou potřebné pro výkon budoucího povolání, jiné jsou nezbytné pro sebepojetí a sociální adaptaci člověka vůbec (Bělecký, 2004/05).

Definice všeobecně užívaná v současné pedagogické praxi ${ }^{14}$ zní: "Klíčové kompetence představují souhrn vědomostí, dovedností, schopností, postojů a hodnot důležitých pro uplatnění každého člena společnosti. Jejich výběr a pojetí vychází z hodnot obecně přijímaných ve společnosti a z obecně sdílených představ o tom, které kompetence přispívají k jeho vzdělávání, spokojenému a úspěšnému životu a k posilování funkcí občanské společnosti."

\section{Další charakteristiky}

Koncept kompetencí není ovšem vyčerpán důležitými dovednostmi (které zahrnují soubor vědomostí a postojů), nebo jejich kombinacemi. Teoreticky jej rozpracoval Franz Weinert, který vycházel z poznatkư psychologie, ty ale propojil s pedagogickými a sociologickými prístupy. Kompetence definoval jakožto "soustavu schopností, dovedností a znalostí, které jsou nutné k dosažení určitého cíle. Mohou jimi být dispozice individuální nebo kolektivní, distribuované v rámci skupiny nebo instituce (Weinert, 2001). Podstatný je jejich vztah k výkonu určité aktivity - v něm se kompetence teprve projevují; kontext výkonu je také specifikuje (Schneckenberg \& Wildt, 2006).

\footnotetext{
${ }^{13}$ Tzv. Lisabonská definice kompetencí. Viz: European Commission: Second Report on the activities of the Working Group on Basic Skills, Foreign Language Teaching and Entrepreneurship. 2003 (Hučínová, 2005)

${ }^{14}$ Objevuje se např. v Rámcovém vzdělávacím programu pro základní vzdělávání, vúP Praha, 2007, s. 14.
} 
Kompetence tak neexistují per se, ale vždy se vztahují k určitému jednání a jeho žádoucímu výsledku (jenž souvisí s požadavky profese, sociální rolí nebo osobním projektem). Projevují se v efektivní akci, kdy jsou mobilizovány další složky. ${ }^{15}$ Tyto akce či jednání probíhají v určitém kontextu, který je třeba brát v úvahu. Hovoří se také o kolektivních kompetencích, protože někdy nemůže jedna osoba všechny tyto složky do svého jednání pojmout (UNECE, 2008: 4).

Pojem kompetence má své podkategorie. Specifické kompetence jsou takové, jež mají význam a uplatnění v určité oblasti nebo oboru. Termín obecné kompetence nabývá více významů či zahrnuje různé koncepty jako např́klad inteligenci, meta-kompetence nebo klíčové kompetence. Všechny tyto obecné modely mají společné to, že mohou nabývat různého obsahu a být aplikovány $v$ různých kontextech. Mají bud' obecnou platnost (tedy mohou se uplatnit za různých situací), nebo souvisí s individuálními schopnostmi a jejich rozvojem.

Specifické kompetence jsou více konkrétní a snadněji měřitelné, zatímco obecné kompetence jsou vhodné pro porovnání různých skupin a situací, jsou ale abstraktní, nejednoznačné a těžce posuzovatelné. Proto existují snahy o sjednocení těchto dvou kategorií, např́klad Bloom (1956) rozlišil ve své známé taxonomii kognitivních kompetencí šest úrovní, od nejvíce specifických po neutrální. Jiný model tzv. akčních kompetencí16 má také obecné a specifické komponenty a zahrnuje všechny kognitivní, motivační a sociální předpoklady pro úspěšné učení a efektivní akci (Allen, Ramaekers \& Velden, 2005).

Kompetence jsou v jistém smyslu sociálním konstruktem, který je založen na hodnotách a ideologických předpokladech. Jsou popisovány jako naučitelné, ale nevyučovatelné. Díky své povaze a podstatě mohou být kompetence pozorovány či hodnoceny jen nepřímo. Je tedy otázka, jak je lze uchopit ve výuce - jednou z možností je zajímat se více o výstupy vzdělávacího procesu (přičemž tradiční přístupy se zajímaly spíše o vstupy, tedy obsahy a metody). Tedy ptát se ne "Co by se studenti měli učit?", ale "Co mají umět, jaké mají mít schopnosti, jaké znát koncepty, užívat strategie pro řešení problémů?" Tím se výsledek procesu učení odliší od „inertních znalostí".

Pěstování kompetencí znamená nutnost systémových změn ve vzdělání, které například umožní rozvíjet interdisciplinární myšlení, komunikaci, schopnost projektového řízení, umění rozhodovat v záležitostech, jež mají komplexní povahu a vyžadují politická řešení. Kompetence vyžadují také změny vzdělávacích standardů, které musí odrážet transformační tendence $v$ celém systému vzdělávání a jeho hodnocení (UNECE, 2008: 4-5). Všechny tyto obecné proměny a požadavky s nimi spojené jsou dưležité zejména z hlediska vzdělání environmentálního, v souvislostech jeho zvláštních nároků na rozvoj systémového myšlení, akčních kompetencí, a především participativního zapojení do společenských struktur a procesů na úrovni vzdělávacích institucí i jednotlivců, kteří se procesu vzdělání účastní.

15 Znalosti, dovednosti, postoje, emoce, hodnoty a motivace - nebo jiné složky podle typu kategorizace), viz UNECE (2008: 4), Sleurs (2004: 39) či další autoři, např. Weinert (2001): "...the theoretical construct of action competence comprehensively combines those intellectual abilities, content-specific knowledge, cognitive skills, domain-specific strategies, routines and subroutines, motivational tendencies, volitional control systems, personal value orientations, and social behaviours into a complex system".

16 akční kompetence = schopnost a dovednost osobitě, iniciativně a zodpovědně přijímat výzvy k pracovním a dalším činnostem a realizovat i samostatně vytčené cíle (ABC slovník cizích slov, viz též Petr Pavlík: Akční kompetence - klíčová složka inteligence 21. století) 


\section{Kompetence jako priorita ve strategických dokumentech EU}

Pojem (klíčové) kompetence se od 90. let minulého století objevuje ve strategických dokumentech EU: vymezila je skupina expertů Rady Evropy v roce 1996 ${ }^{17}$, jsou definovány v cíli 1.2 Lisabonského procesu: „Rozvíjet klíčové kompetence ve společnosti založené na znalostech". ${ }^{18}$ Dle nich mají především být identifikovány a zahrnuty do kurikulí.

Identifikaci klíčových kompetencí provedla pracovní skupina Evropské komise, která také navrhla doporučení pro vzdělávací politiky členských zemí a přistupujících států EU. Pracovní skupina Evropské komise vycházela při výběru klíčových kompetencí především ze závěrů studie DeSeCo ${ }^{19}$, vytvořené pod záštitou OECD.

Na zasedání OECD (Organizace pro hospodářskou spolupráci a rozvoj, jejímž členem je i Česká republika), byl v dubnu 2001 definován nový mandát pro aktivity v oblasti vzdělávání pod názvem "Investujme do kompetencí pro všechny". 20 Výsledky jednání OECD tvoří základní myšlenkový rámec pro zdokonalování vzdělávacích strategií; jednou z nejdůležitějších priorit je: „Rozvoj lidských kompetencí vyžadovaných soudobou společností a ekonomikou znalostí a jejich získávání v průběhu celého života." (Též Bílá kniha, 2001).

17 Skupina expertů Rady Evropy vymezila $v$ sedmi skupinách celkem 39 klíčových kompetencí (dovedností a schopností), které jsou členěny do 7 okruhů. Tyto kompetence by měl každý člověk $v$ moderní společnosti mít a škola by je měla rozvíjet (viz Bělecký, 2004/05):

1. Učení

2. Objevování

3. Myšlení a uvažování

4. Komunikace

5. Kooperace

6. Práce

7. Adaptace

18 Lisabonská strategie pro období 2000 - 2010 přijatá Radou Evropy v březnu 2000 má své cíle i v oblasti vzdělávání. V březnu 2000 vytyčila v Lisabonu Rada Evropy hlavní strategický cíl pro evropské společenství pro období 2000-2010: Evropa by se měla "stát nejkonkurenceschopnější a nejdynamičtější ekonomikou na světě, která čerpá ze znalostí a dovedností a je schopna nepřetržitého hospodářského rưstu při současném dosažení většího množství lepších pracovních príležitostí a větší sociální soudržnosti".

Členské státy identifikovaly 5 základních prioritních oblastí politik, ve kterých by EU a členské státy měly pokročit, aby si tak zajistily nejen svou vlastní dynamiku, ale i sílu celé evropské ekonomiky, ze které samy profitují. Prvním z nich je: „Realizace společnosti založené na znalostech".

účastníci summitu se shodli mimo jiné na společných cílech, kterých se budou snažit dosáhnout $\checkmark$ rámci Lisabonské strategie $v$ oblasti vzdělávání. $O$ dva roky později pak členské země EU odsouhlasily pět ukazatelů, podle kterých se bude pokrok hodnotit. Více viz: European Commission: Education And Training 2010 Diverse Systems, Shared Goals - Progress towards the Lisbon objectives in education and training - Indicators and benchmarks (EN) [Online] [Cit-2009-03-03] Dostupné z www: <http://ec.europa.eu/education/policies/2010/progressreport en.html>

19 Program "Definition And Selection of Competencies": teoretický a koncepční program zahájený $v$ roce 1997 a ukončený v roce 2002. [Online] [Cit-2009-03-03] Dostupné z www: <http://www.oecd. org/dataoecd/47/61/35070367.pdf>

Viz též Závěrečná zpráva: Dominique Simone Rychen and Laura Hersh Salganik (eds.) Key Competencies for a Successful Life and a Well-Functioning Society. Hogrefe \& Huber, Göttingen, 2003.

${ }^{20}$ Závěry z konferencí ministrů školství členských zemí OECD,Paříž, 3. - 4. dubna 2001. [Online] [Cit-2009-03-03] Dostupné z www: <http://aplikace.msmt.cz/MezinarodniSpoluprace/ Dokumenty/OECDkomunike.doc > 
Pro Evropský region je důležité také doporučení Evropského Parlamentu a Rady z 18. prosince 2006 týkající se klíčových kompetencí pro celoživotní vzdělávání. ${ }^{21}$

\section{Kompetence $v$ českém školství}

Ucelenou koncepci vzdělávací politiky představuje Národní program rozvoje vzdělání v České republice, tzv. Bílá kniha, jež byla vytvořena v roce 2001 a přijata napřič politickým spektrem. Na ni navazují tzv. rámcové vzdělávací programy (RVP), které jsou v současné době uváděny do života (Spilková, 2004).

Základní charakteristikou RVP je důraz na všestrannou kultivaci osobnosti, což zahrnuje mj. rozvoj kompetencí, které jsou chápány jako "soubor komplexních způsobilostí využitelných v životě a v dalším vzdělávání", konkrétněji jako "souhrn vědomostí, dovedností, schopností, postojů a hodnot" důležitých pro osobní rozvoj jedince, jeho aktivní zapojení do společnosti a budoucí uplatnění v životě. Za klíčové jsou považovány kompetence k učení, k řešení problémů, komunikativní, sociální a personální, občanské a pracovní (Bělecký, 2004/05).

Cílem vzdělávání v RVP22 se stává nikoli učivo - to je jen prostředkem k získání klíčových kompetencí. Úkolem vyučujících není „probrat učivo", ale prostřednictvím učiva vybavit žáky kompetencemi. Tyto nové rysy v pojetí kurikula mají transformační potenciál, promítají se do „podpory rozvoje klíčových kompetencí jako nástroje přeměny encyklopedického pojetí vzdělávání" (Bílá kniha, str. 39). Kompetence se staly jedním z cílů kurikulární reformy. ${ }^{23}$

Kompetence bývají pojímány dvěma způsoby: bud' více či méně předmětově, nebo jako kompetence všeobecné, nadpředmětové (s oběma modely se Ize setkat v současných evropských kurikulích) (Hučínová, 2005). Potřebu integrace už zavedených předmětů mají $\checkmark$ rámcových vzdělávacích programech naplňovat tzv. prưřezová témata. To odráźí

21 Recommendation of the European Parliament and of the Council, 18 December 2006 on key competences for lifelong learning (2006/962/EC) [Online] [Cit-2009-03-03] Dostupné z www: <http://eur-ex.europa.eu/LexUriServ/site/en/oj/2006/l 394/l 39420061230en00100018.pdf>

22 Konkrétní cíle a obsah vzdělávání stanoví Rámcové a Školní vzdělávací programy. Vzdělávací cíle vychází z nového pojetí, které je založeno na vyváženosti poznatkového základu, rozvoje kompetencí a osvojování postojů a hodnot. Jeho cíle jsou následující:

v oblasti postojů, vztahů k hodnotám - emotivní oblast (dodržovat daná pravidla, tolerance k názorům druhých, chránit životní prostředí aj.).

v oblasti dovedností a kompetencí - konativní oblast (manuální dovednosti, různé činnosti, umět diskutovat, vyhledávat informace).

v oblasti znalostí, vědomostí - kognitivní oblast (konkrétní znalosti, vědomosti, fakta - např. historické údaje, matematické vzorečky, cizí slova aj.).

Vzdělávací program (kurikulum) obsahuje kromě specifických cílů, obsahu a podmínek pro vzdělávání také výstupní klíčové kompetence. $\mathrm{K}$ cílům vzdělávání musí směřovat používané metody a formy (Václavík, 2004)

${ }^{23}$ Rámcový vzdělávací program pro základní vzdělávání, část Kompetence k řešení problémů (Sárközi, 2006):

Na konci základního vzdělávání žák:

vnímá nejrůznější problémové situace ve škole i mimo ni, rozpozná a pochopí problém, přemýšlí o nesrovnalostech a jejich přícinách, promyslí a naplánuje způsob řešení problémů a využívá $\mathrm{k}$ tomu vlastního úsudku a zkušeností

vyhledá informace vhodné k řešení problému, nachází jejich shodné, podobné a odlišné znaky, využívá získané vědomosti a dovednosti $k$ objevování rưzných variant řešení, nenechá se odradit př́padným nezdarem a vytrvale hledá konečné řešení problému

samostatně řeší problémy; volí vhodné způsoby řešení; užívá při řešení problémů logické, matematické a empirické postupy

ověřuje prakticky správnost řešení problémů a osvědčené postupy aplikuje při řešení obdobných nebo nových problémových situací, sleduje vlastní pokrok při zdolávání problémů

kriticky myslí, činí uvážlivá rozhodnutí, je schopen je obhájit, uvědomuje si zodpovědnost za svá rozhodnutí a výsledky svých činů zhodnotí 
skutečnost, že reálné problémy Ize jen zřídka vysvětlit v kontextu poznatků jedné disciplíny. ${ }^{24}$ Existuje však také názor, že všechny skutečné kompetence ze své podstaty překračují předmětové hranice, i když jsou třeba zařazeny pod hlavičku oboru (pokud by předměty zůstaly izolované a nekomunikovaly spolu navzájem, nebylo by možné vybudovat obecnou připravenost a vybavenost žáka pro to, aby prováděl životně nebo odborně významné činnosti a podával určité výkony) (Hausenblas, 2004).

Kompetence jakožto vzdělávací kvality s jistými charakteristikami (především více či méně komplexní povahou, jejíž složky se projeví až v akci) mají své místo i na vyšších stupních vzdělání, ačkoli na této úrovni nejsou v ČR předmětem široké odborné diskuze.

\section{Závěr}

V textu navržená zastřešující kategorie kvality ve vzdělání, pod kterou shrnujeme méně obecné pojmy označující výstupy vzdělávacího procesu (znalosti, kompetence či jiné individuální dispozice, jejichž rozvoj je cílem výchovného pưsobení) rozšiřuje a zpřesňuje dosavadní terminologii. Díky vysoké míře zevšeobecnění poskytuje podklad pro sjednocení více specifických pojmů, umožňuje činit obecné závěry týkající se transformace vzdělávacích systémů, a je základem srovnatelnosti jednotlivých fází v tomto vývoji. Umožňuje pak také přesnější odlišení dosud užívaných termínů (na základě jejich společných a rozdílných rysů), a dále stanovení kritérií, podle kterých lze usuzovat o jejich naplnění určitým obsahem. Z takových úvah teprve může být vyvozeno, co se rozumí kvalitou v pravém slova smyslu, co je indikátorem těchto kvalit; a z toho také vyplývá, jak určovat vzdělávací cíle nebo jaké nástroje volit pro hodnocení výsledků vzdělávacího procesu a prípadně jak by se měly kombinovat různé ukazatele či faktory takové evaluace. Jako př́klad jsme vybrali př́buznou terminologii v článku Jana Činčery (2009), ukázali rozdíly či nástrahy při užití pojmů svým obsahem zdánlivě velmi podobných: termín kompetence Ize zahrnout mezi vzdělávací kvality, je vzdělávacím cílem, ke kterému Ize orientovat metodické nástroje; na druhé straně proenvironmentální chování je spíše indikátorem této kvality, tedy nikoli samo o sobě vzdělávacím cílem. Je třeba s ním pracovat právě jakožto s indikátorem, tedy usilovat o jeho operacionalizaci, a také nalezení takové funkce, která by $v$ následné evaluaci zohlednila dílčí složky tohoto proenvironmentálního chování nebo předpoklady pro jeho rozvoj.

Významné změny $v$ posuzování přínosů vzdělávacího procesu (související nejen s novou společenskou situací a jejími požadavky, ale i s připomenutím si tradičních všeobecných cílů, jež právě v této nové situaci osvědčují svoji platnost) se projevují jako posun $v$ porozumění důležitým pojmům a $v$ přesunu koncepčních důrazů - praktickým výrazem těchto změn je zvýšené užívání termínu kompetence. Jde o nově stanovený cíl vzdělání, který má zahrnout nové kvality pěstované všeobecně, na všech úrovních vzdělávacího systému. Koncept kompetencí se opírá o jistou „přidanou hodnotu" ve vzdělávacích výstupech, ponechává sice tradiční členění na znalosti, dovednosti a postoje, doplňuje je ale o akční rozměr, schopnost využít získané schopnosti při řešení praktických úkolů. Filosofie těchto změn, která zaměřuje pozornost na dynamické procesy v samotném učení i následné životní praxi, je určující vizí a motivem pro současné transformační procesy ve vzdělávání.

\footnotetext{
${ }^{24}$ Environmentální výchova jakožto průřezové téma má tedy základ v četných oborech prírodovědných i společenskovědních, a jeho výuka je oborově integrovaná. Postupné propojování, rozšiřování, upevňování i systematizace vědomostí a dovedností získávaných v těchto oblastech přispívá $\mathrm{k}$ utváření celostního pohledu; porozumění souvislostem má umožnit řešení problémů praxe. Obsah prưřezového tématu (především na středoškolské úrovni) je proto zpracován $v$ podobě problémových otázek, z nichž každá zahrnuje řadu dílčích problémů. Celkově má environmentální výchova vést k pochopení komplexnosti a složitosti vztahů člověka a životního prostředí.
} 
V této souvislosti jsou za žádoucí vzdělávací výstupy považovány kompetence, a ty pak poukazují k tzv. dynamické kultuře učení, která počítá s individuální angažovaností v učení i při využití poznatků, má povahu participativní (mění roli učitele a žáka), vzdělávací kvality hodnotí s ohledem právě na tyto aktivní prvky. Je založena na teorii učení, která podmiňuje porozumění vyučované problematice spoluúčastí na hledání skutečných problémů a jejich řešení (Posch, 1994). Vychází z teorie reflexivní akce 25 a významně se odlišuje od relativně "statické" či "standardizované" kultury učení, v rámci níž se předpokládá, že proces výuky/učení může být předem určen. Tato statická kultura počítá také s jednoduše a předem definovanými vzdělávacími výstupy, o míru jejichž naplnění jde (znalosti). Srovnání viz tabulka 2. Koncept kompetencí je tak př́značný pro poměrně zásadní změnu vzdělávacích východisek.

\section{Tabulka 2. Srovnání základních rysů statické a dynamické kultury učení podle} Schöna (1983)

\begin{tabular}{|c|c|}
\hline $\begin{array}{l}\text { Tzv. „statický“ systém vzdělání a jeho } \\
\text { omezení: }\end{array}$ & $\begin{array}{l}\text { Dynamická kultura učení založená na } \\
\text { aktivním přístupu: }\end{array}$ \\
\hline $\begin{array}{l}\text { Filosofickým pozadím „statického" přístupu } \\
\text { je technická racionalita, která je založena } \\
\text { na třech předpokladech: } \\
\text { - praktické problémy mají obecná řešení; } \\
\text { - tato řešení mohou být vyvinuta vně } \\
\text { praktických situací (například } \\
\text { v akademických nebo administrativních } \\
\text { centrech); } \\
\text { - tato řešení mohou být přenesena na } \\
\text { praktickou úroveň, kde vyřeší praktické } \\
\text { problémy. } \\
\text { Výsledkem těchto závěrů je oddělení teorie }\end{array}$ & $\begin{array}{l}\text { K vytvoření dynamických kvalit studentů by } \\
\text { mělo vést aktivní učení: } \\
\text { - u studentů by měla vzniknout forma } \\
\text { porozumění, kterou Ize nazvat "situační" - } \\
\text { zahrnuje více zvláštní, praktické okolnosti, } \\
\text { než abstraktní teorie. Výzkumné metody, } \\
\text { které mají vést k praktickému porozumění, } \\
\text { se budou lišit od těch, které mají vyústit } \\
\text { v zobecnění platná v teorii. První se budou } \\
\text { zabývat shromažd'ováním podkladů, které } \\
\text { umožní "přečíst", interpretovat celkovou } \\
\text { situaci; druhé údajů, jež umožní }\end{array}$ \\
\hline
\end{tabular}

${ }^{25}$ Viz (Schön, 1983): Teoretickým základem [dynamické kultury učení jakožto] alternativy ke statické kultuře výuky/učení a technické racionality, je dynamické učení, reflexivní racionalita a teorie reflexivní akce. ... Díky vzrůstající potřebě čelit komplexním, jedinečným problémům budou autonomní akce vyžadovány od stále většího počtu lidí. Vzhledem $k$ tomu byla vytvořena nová epistemologie praxe; její součástí je právě teorie reflexivní akce, která popisuje tři stadia, jimiž provedení akce prochází:

- normálním stavem jsou "nevyslovené znalosti v akci" - je to spontánní chování v nacvičené praxi; aktivitám nepředchází intelektuální operace; jednající o znalostech, jež jsou podkladem jednání, ani neví. Činnosti jsou výsledkem socializace a navyklých forem chování

- $\quad$ reflexe $v$ akci - je nutná v případě, že praxe nabízí divergentní situace. Čelíme-li jim, stáváme se nezávislými na zavedené teorii - je třeba vytvořit teorii vyhovující zvláštnímu prípadu. Při výzkumu dané situace nemůžeme oddělit prostředky a cíle - definujeme je $v$ závislosti na okolnostech; myšlení nemůžeme oddělit od akce - je prostředkem k akci; příśtí využití je zabudováno do zkoumání situace.

- reflexe o akci - nastává, když jednající vystoupí z proudu akce, distancuje se od ní a objektivizuje ji. Reflexe je sekundární akcí - primární akce se stává objektem pozorování. Lze tak získat data popisující situaci a uchovat je $v$ materiální formě - to je podmínkou vytvoření společného základu praktického poznání. $V$ tomto přístupu platí, že jevy nelze interpretovat navyklými způsoby - musíme být citliví k nepředpokládaným efektům. Nemůžeme své aktivity hodnotit slovy "Dosáhl jsem, co jsem zamýšlel?"; hlavním zájmem je spíše celkové porozumění situaci. Experiment je neúspěšný, jestliže všechny účinky i vedlejší účinky jsou posuzovány jako změna k horšímu, a naopak. Činnost se uskutečňuje ve spirálovitém procesu uvědomování si, akce a znovuuvědomování.

Reflexivní racionalitu Ize využít k vypracování modelu institucionálních změn - (vzdělávací) struktury "se brání" realitě, se kterou jsou konfrontovány; je však mezi nimi nutný "dialog" vedoucí k rekombinaci struktur, aby nedošlo ke vzájemnému konfliktu." 
Tzv. „statický" systém vzdělání a jeho omezení:

a praxe, znalostí a aktivit, prostředků a výsledků; v jejich důsledku vznikají dvě hierarchie: hierarchie poznání a hierarchie důvěryhodnosti.

Základní výzkum, aplikovaná věda a technické dovednosti každodenní praxe představují hierarchii poznání - obecná, teoretická věda má v jejím rámci privilegované postavení.
Dynamická kultura učení založená na aktivním přístupu:

abstrahovat obecné ze zvláštního. Formou

takového praktického výzkumu jsou

prípadové studie...

- studenti by se měli zbavit

metodologického dogmatismu ve vztahu

k učiteli; mají totiž tendenci být

intelektuálně závislí na metodologických požadavcích. Výzkumné metody, které poměřují výsledky se závazně platnými významy, jsou pro tento účel zavádějící. Studenti by si měli osvojit praktické kompetence - zahrnující jak technickou způsobilost, tak etický rozměr. Při praktických činnostech je manifestována určitá „moudrost", což je archaičtější termín pro „situační porozumění".

Kurikula by se s ohledem na požadavky "dynamické" kultury učení měla umět vyrovnávat s následujícími situacemi: - málo strukturovanými, to znamená, že problémy, které mají být řešeny, musí být teprve jasně definovány. Takové výukové situace se významně liší od normálních instruktivních situací, ve kterých je studentům nabízena předem strukturovaná a systematická informace;

- realistickými, takovými, které vyžadují holistický přístup, prưřez rưznými

disciplínami a rozmanité dovednosti včetně kreativních a organizačních. Tyto situace zase nenajdeme v klasických instruktivních metodách, které jsou zaměřeny převážně na získání zásoby vědomostí

- takovými, které rozvíjejí osobní hlediska a vlastní úsudky $v$ př́tomnosti nejednoznačnosti a protikladů. Pro to je zapotřebí určitá úroveň reflexe, zvažování očividných jistot a také tolerance pro jiná hlediska a názory - což normálně nelze vyžadovat od oborové výuky. 
Časopis Envigogika vydává Centrum pro otázky životního prostředí UK. Vývoj časopisu je podpořen projektem OP VK Mezioborová sít udržitelného rozvoje.

Více najdete na internetových stránkách projektu mosur.czp.cuni.cz
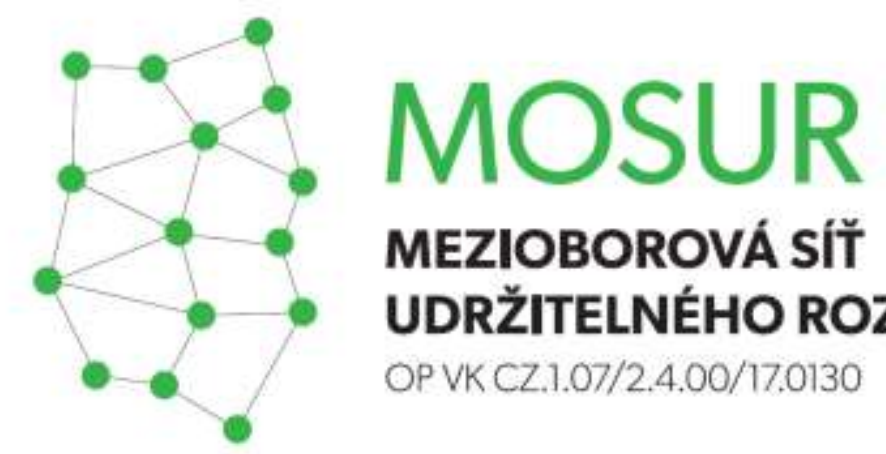

\section{MEZIOBOROVÁ SÍT} UDRŽITELNÉHO ROZVOJE

OP VK CZ.1.07/2.4.00/17.0130
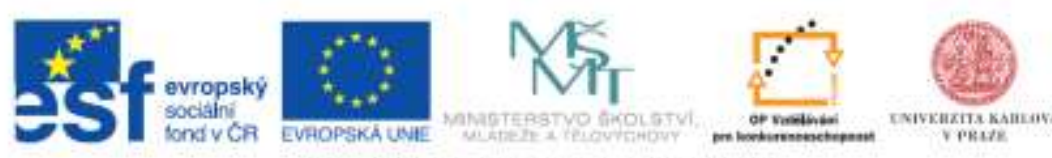

INVESTICE DO ROZVOJE VZDELAVANI 